\title{
HYGIENIC SANITARY ESTIMATION OF MAIZE SILAGE IN DAIRY FARMS IN LITHUANIA
}

Jurgita JOVAIŠIENE், Department of Food Safety and Quality, Veterinary Academy of Lithuanian University of Health Sciences, Tilžès 18, LT-47181, Kaunas, Lithuania, jurgita.jovaisiene@1smuni.lt (corresponding author)

Bronius BAKUTIS, Department of Food Safety and Quality, Veterinary Academy of Lithuanian University of Health Sciences, Tilžès 18, LT-47181, Kaunas, Lithuania, bronius.bakuti@1smuni.lt

Violeta BALIUKONIENĖ, Department of Food Safety and Quality, Veterinary Academy of Lithuanian University of Health Sciences, Tilžès 18, LT-47181, Kaunas, Lithuania, violeta.baliukoniene@1smuni.lt

Audrius KAČERGIUS, Vokė Branch, Lithuanian Research Centre for Agriculture and Forestry, Žalioji a. 2, Trakų Vokè, LT-58344, Vilnius, Lithuania. audrius.kacergius@,voke.lzi.lt

Algimantas PAŠKEVIČIUS, Institute of Botany of Nature Research centre, Biodeterioration Research Laboratory, Žaliujų Ežerų g. 37, LT-08406, Vilnius, Lithuania. algimantas.paskevicius@,botanika.lt

Gediminas GERULIS, Department of Food Safety and Quality, Veterinary Academy of Lithuanian University of Health Sciences, Tilžès 18, LT-47181, Kaunas, Lithuania, gediminas.gerulis@1smuni.lt

\begin{abstract}
The aim of this study was to estimate maize silage hygienic sanitary parameters, contamination with mycotoxins in dairy farms in Lithuania. In 2011-2012 maize silage samples were collected from 20 dairy farms: prior to ensiling and 3 and 8 months after ensiling. In maize samples, prior to ensiling, L. monocytogenes was detected $25.0 \%$ and after 3 months of ensiling $-10 \%$. Average of yeast and filamentous fungi in raw material samples were respectively $-71.39 \pm 32.17$ and $47.67 \pm 18.31 \mathrm{CFU} / \mathrm{g}$, after 3 months $-50.06 \pm 16.09$ $\mathrm{CFU} / \mathrm{g}$ and $28.27 \pm 13.18$, after 8 months $-213.81 \pm 55.98$ and $215.08 \pm 56.16 \mathrm{CFU} / \mathrm{g}$. In raw maize dominated Fusarium spp. and in silage - Aspergillus, Penicillium spp.

Average of lactic acid bacteria $-189.01 \pm 57.79$ (3 months after ensilage) and $436.11 \pm 93.97 \mathrm{CFU} / \mathrm{g}$ ( 8 months after ensilage).

Compared prior to ensilage and 3 and 8 months after ensilage maize samples, higher mycotoxins concentrations of DON $-36.96 \%(\mathrm{P}<0.05)$ and ZEA-77.32\% $(\mathrm{P}<0.05)$ were detected in 3 month after ensilage, T-2 toxin $-72.69 \%(\mathrm{P}<0.05), \mathrm{AFL}-94.31 \%(\mathrm{P}<0.05)$ were detected in 8 month after ensilage. Concentration of OTA was higher $34.99 \%(\mathrm{P}>0.05)$ in samples after 3 months of ensiling.

Dry matter and $\mathrm{pH}$ respectively: prior to ensiling $-36.96 \%$ and 5.26, 3 months after ensiling $-33.17 \%$ and $3.84,8$ months after ensiling $-40.52 \%$ and 3.91 .

The current results indicate the presence of yeast, viable fungi spores and mycotoxins AFL (total), ZEA, DON, T-2 and OTA contamination in maize silage in Lithuania.
\end{abstract}

Keywords: fungi, maize silage, mycotoxin, yeast.

\section{INTRODUCTION}

Maize silage is a widely used feed product for cattle. In many countries around the world, the production of maize silage is equal to or larger than the production of grass silage (Wilkinson and Toivonen, 2003). In the climatic conditions of Lithuania, fresh fodder needs to be made into silages or another kind of forage to supply cattle with succlent forage during the year (Baležentienè and Mikulionienè, 2006). In Lithuania the production of maize for silage -31 ton/ha.

The quality of raw milk and dairy products is related primarly to the quality of silage fed to cows. The kind of raw material and environmental conditions determine the composition of epiphytic microflora on the surface of the vegetative parts of green plants, thus affecting the final microbiological quality of silage. One of the quality-related problem is low aerobic stability for silage, which causes an increase in the Listeria monocytogenes count (raw material contamination with these microorganisms may cause the occurrence of listeriosis in animals). A high dry matter concentration $(>50 \%)$ in the raw material makes silage more susceptible to self-heating and infestations with toxin-producing fungi. The progress observed in silage production technologies primarly concerns maize silage and maize grain silage, whose quality depends upon the growth stage. Delayed harvest aimed at achieving a high dry matter yield results in the mass proliferation of yeasts and mould. Consequently, maize silage has the highest dynamics of changes in microbiological quality (Purwin et al., 2006).

The aim of the current study was to estimate micro-organisms present in maize silage and contamination with mycotoxins during storage period in dairy farms in Lithuania.

Copyright $\odot 2015$ The Authors. Published by Aleksandras Stulginskis University. This is an open-access article distributed under the terms of the Creative Commons Attribution License (CC-BY 4.0), which permits unrestricted use, distribution, and reproduction in any medium, provided the original author and source are credited. 


\section{MATERIAL AND METHODS}

During 2011-2012 maize silage samples were collected from 20 farms of four geographic regions (five farms in each of the four regions) in Lithuania. Samples were collected at harvest and the again at the same site 3 and 8 months after ensiling. Samples were stored $4{ }^{\circ} \mathrm{C}$ prior to processing.

Listeria monocytogenes in raw and ensiled maize silage was detected according LST EN ISO 11290-1:2003/A1:2005.

For identification of yeast, mould count performed according LST EN ISO 7954 „Microbiology. General guidance for enumeration of yeasts and moulds. Colony-count technique at $25^{\circ} \mathrm{C}$ “. For identification of lactic acid bacteria (LAB) count performed according LST ISO 15214:2009 „Microbiology of food and animal feeding stuffs - Horizontal method for the emumeration of mesophilic lactic acid bacteria - Colony-count technique at $30{ }^{\circ} \mathrm{C}$ (ISO $15214: 1998$, identical)“. In determining the silage sample for direct fungal infection that occur in the parts of the sample surface, the percentage of external exposure to viable mycelium of fungi was estimated. For purification and identification of fungi isolates, the samples were inoculated on Czapek-Dox agar and Malt extract agar and cultivated at $26 \pm 2{ }^{\circ} \mathrm{C}$ for $5-7$ days. The isolates were ascribed to taxonomic groups following Ainsworth and Bisby's Dictionary of Fungi (Hawksworth et al., 1995). Fungi were identified according to various manuals (Nelson et al., 1983; Pitt, 1997; Klich, 2002; Lugauskas et al., 2002; Samson et al., 2002). The isolation frequency (FO) of genera was calculated.

Mycotoxins analysis. Whole silage samples were air dried at $70{ }^{\circ} \mathrm{C}$ for $24 \mathrm{~h}$ in an oven, ground to pass a $1 \mathrm{~mm}$ screen and homogenized. The silage samples were determined by direct competitive enzyme-linked immunosorbent assays (ELISA) (AOAC, 2000).Contamination of silage with deoxynivalenol (DON), T-2 toxin, zearalenone (ZEA) and aflatoxins (AFL (total)) Ochratoxin A (OTA) was tested with the RIDASCREEN test kits ('R-Biopharm AG', Germany). Mycotoxin extraction and tests were performed according to manufacturer's instructions. Absorbance was determined using the microwell strip reader (Neogen, USA) at $450 \mathrm{~nm}$. The measured absorbance was converted to the mycotoxin concentration units $-\mu \mathrm{g} / \mathrm{kg}(\mathrm{ppb})$.

Dry matter (DM) was analyzed on the day of sampling. To determinate dry matter, samples were chopped in $4 \mathrm{~cm}$ -diameter-particles and dried for 18 hours at $55^{\circ} \mathrm{C}$. After air equilibration, the samples were weighed and then dried again for 20 hours at $103{ }^{\circ} \mathrm{C}$ (AOAC, 2005). The $\mathrm{pH}$ was measured in diluted silage with a pH-meter (WTW@inoLab pH 720) fitted with a glass electrode after homogenization of $10 \mathrm{~g}$ silage with $40 \mathrm{ml}$ of distilled water.

Statistical analyses were carried out using SPSS software (version 17.0 for Windows, SPSS Inc., Chicago, IL, USA). The data were analyzed by analysis of variance (ANOVA). Specific means differences were identified with LSD 's multiple range tests.

\section{RESULTS}

L. monocytogenes were isolated from $25 \%$ prefermented maize samples and from $10 \%$ postfermented samples.

In prior to ensiling and ensiled silage samples taken from a trench-type silo were determined the different number epiphytic microflora (Fig. 1). Filamentous fungi and yeast counts in raw maize were highest respectively $39.61 \%$ $(\mathrm{P}>0.05)$ and $29.88 \%(\mathrm{P}>0.05)$ then in 3 months silage samples after ensiling and respectively lowest $22.16 \%$ $(\mathrm{P}<0.05)$ and $33.39 \%(\mathrm{P}<0.05)$ then in samples 8 months after ensiling. LAB count in samples $(3$ months after ensiling $)$ were lowest $56.66 \%(\mathrm{P}<0.05)$ then in samples 8 months after ensiling.

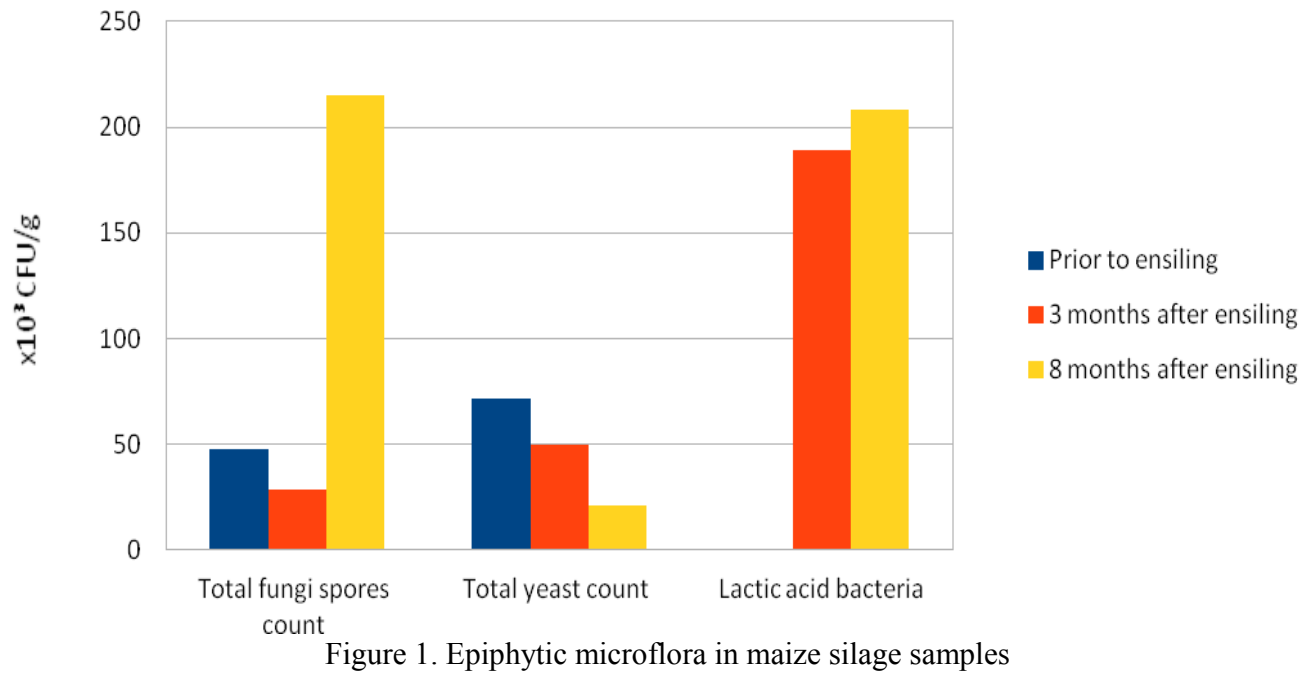

Filamentous fungi were isolated from all raw and silage samples. Table 1 shows the isolation frequency (\%) of different fungal genera from pre- and postfermented maize samples. Six genera of filamentous fungi were dominated by other fungi. Less frequent species were Acremonium spp., Curvularia spp., Rizophus spp., Trichoderma spp. The most commonly isolated filamentous fungi in raw maize were Alternaria spp. (73.9 \%), Fusarium spp. (34.1\%). Predominant Fusarium spp. species were F. sporotrichioides, F. poae, F. graminearum. A high frequency of Zygomycetes was also 
found, primarily Mucor.

The most commonly isolated filamentous fungi (3-months and 8-months after ensilage) were Aspergillus spp. and Penicillium spp. (Table 1). Predominant Aspergillus spp. after the 3-months and 8-months ensilage respectively were $A$. fumigatus (4.88 \% and $9.00 \%)$, A. niger (15.00\% and $4.29 \%)$. Less frequent species were Trichoderma spp. and Byssochlamys spp.

Table 1. The frequency of occurrence of fungal genera in pre - and postfermented silage samples

\begin{tabular}{|l|c|c|c|}
\hline \multirow{2}{*}{ Fungal genera } & \multicolumn{3}{|c|}{ Frequency of occurrence \% } \\
\cline { 2 - 4 } & Raw (prefermentation) & 3 month ensiling & 8 month ensiling \\
\hline Acremoniella & 2.6 & - & - \\
\hline Alternaria & 73.9 & - & 61.83 \\
\hline Aspergillus & - & 30.47 & 3.3 \\
\hline Byssochlamys & - & 3.87 & - \\
\hline Cladosporium & 4.0 & - & - \\
\hline Fusarium & 34.1 & - & 45.45 \\
\hline Helminthosporium & 1.3 & - & 9.59 \\
\hline Mucor & 21 & 2.0 & - \\
\hline Penicillium & - & 22.9 & 0.6 \\
\hline Trichoderma & - & 6.24 & - \\
\hline Other & 0.3 & 2.6 & \\
\hline
\end{tabular}

From twenty tested prefermented silo samples - three samples were positive for AFL (total). Only four samples (20\%) of 3 month postfermented silo and three samples $(25 \%)$ of 8 month postfermented silo were negative to AFL (total) (Table 2).

Fusarium mycotoxin (ZEA, DON, T-2) levels in prefermented and postfermented silage samples are shown in Table 2.

Table 2. Concentrations of mycotoxins from pre - and postfermented silage samples

\begin{tabular}{|l|c|c|c|}
\hline \multirow{2}{*}{ Mycotoxins } & \multicolumn{2}{|c|}{ Period } & 8 month ensiling \\
\cline { 2 - 4 } & Raw (prefermentation) & 3 month ensiling & $100.0-2000.0$ \\
DON $(\mu \mathrm{g} / \mathrm{kg})$ & $<18.5-3500.0$ & & \\
Min-Max & $1640.0 \pm 40.0^{\mathrm{b}}$ & $480.0-5300.0$ & $<10.0 \pm 17^{\mathrm{c}}$ \\
Mean \pm SD & & $2600.0 \pm 260.0^{\mathrm{a}}$ & $<-700.0$ \\
\hline ZEA $(\mu \mathrm{g} / \mathrm{kg})$ & $0.6-400.0$ & $100.0-1300.0$ & $380.42 \pm 19.20^{\mathrm{b}}$ \\
Min-Max & $206.88 \pm 7.31^{\mathrm{c}}$ & $880.04 \pm 60.62^{\mathrm{a}}$ & $28.0-226.0$ \\
Mean \pm SD & & & $147.25 \pm 20.8^{\mathrm{a}}$ \\
\hline T-2 $(\mu \mathrm{g} / \mathrm{kg})$ & $<20.0-325.0$ & $16.0-394.0$ & $<0.0004-47.5$ \\
Min-Max & $40.21 \pm 18.23^{\mathrm{b}}$ & $141.48 \pm 23.37^{\mathrm{a}}$ & $20.05 \pm 5.33^{\mathrm{a}}$ \\
Mean \pm SD & & & \\
\hline AFL $($ total $)(\mu \mathrm{g} / \mathrm{kg})$ & $<0.0004-6.6$ & $<0.0004-62.3$ & $<2.5-58.0$ \\
Min-Max & $0.94 \pm 0.51^{\mathrm{b}}$ & $16.86 \pm 3.96^{\mathrm{a}}$ & $18.95 \pm 4.86^{\mathrm{a}}$ \\
Mean $\pm \mathrm{SD}$ & & & \\
\hline OTA $(\mu \mathrm{g} / \mathrm{kg})$ & - & $29.15 \pm 60.0$ & $6^{\mathrm{a}}$ \\
Min-Max & & & \\
Mean \pm SD & & & \\
\hline
\end{tabular}

Values in the same row with different following letters are significantly different $(\mathrm{P}<0.05)$, LSD's multiple range test

ZEA, DON, AFL (total) and T-2 mycotoxin levels between prefermented and postfermented silage samples were significantly different $(\mathrm{P}<0.05)$. T-2, AFL (total) and OTA levels between 3 month and 8 month postfermentation did not showed significant differences $(\mathrm{P}>0.05)$.

In the collected maize samples DM and $\mathrm{pH}$ respectively: prior to ensiling $36.96 \%$ and 5.26, after 3 months of ensiling $-33.17 \%$ and 3.84 , after 8 months of ensiling $-40.52 \%$ and 3.91 .

\section{DISCUSSION}

The current study includes 20 dairy farms from four regions of Lithuania. The $\mathrm{pH}$ was recorded for all prefermented and postfermented maize samples. The average $\mathrm{pH}$ with the L. monocytogenes positive prefermented samples was $5.34 \pm 0.23$ and postfermented $-3.91 \pm 0.17$. In 2005 year Borucki et al. reported about statistically significant $(\mathrm{P}<0.05)$ the differences between the average $\mathrm{pH}$ of negative and positive samples with L. monocytogenes. In this study the average $\mathrm{pH}$ of the positive silage samples was 4.62 compared to an average $\mathrm{pH}$ of 4.4 for the $L$. monocytogenes - negative samples.

In the present study, the biggest total fungi spores and lactic acid bacteria count and the lowest yeast count were detected in samples 8 month after ensilage. In Storm et al. study (2010) the highest numbers of fungi were five to seven and the lowest 11 months after ensiling, while the LAB decreased in numbers during the study.

Making silage in good conditions anaerobiosis and low $\mathrm{pH}$ usually prevents the development of fungi (Yiannikouris and Jouany, 2002). Fusarium spp., Aspergillus spp., Penicillium spp., the main mycotoxicogenic moulds, 
were the prevalent genera. A high frequency of Zygomycetes was also found. These resultas are in agrement with Pereyra et al. (2007) in corn silage samples who found Aspergillus spp., Penicillium spp. and Mucor as prevalent genera. A. fumigatus and A. niger showed the highest relative density among Aspergillus species. The current result agrees with Garon et al. (2006) where A. fumigatus were isolated after 4-month sampling of corn silage in France.

In Lithuania, the weather conditions are favorable for the occurrence fungi. As a result, of fungi growth, the food products and animal feed are often contaminated by mycotoxins (Baliukoniene et al., 2012). The analytical results for mycotoxins indicated that raw maize and maize silage samples were contaminated with different AFL (total), OTA, ZEA, DON, T-2 concentrations. AFL (total) intoxication in dairy cattle is characterized by liver cell injury, a fatty liver syndrome (pale livers), poor feed conversion, and a significant reduction in milk yield (EFSA, 2004). In the present study, the respectively highest $95.3 \%$ and $15.9 \%$ AFL (total) concentrations were found in silage samples 8 month after ensilage than in raw maize sample or in 3 month after ensilage. The current result did not agree with Pereyra et al. (2006) where prefermented samples did not show $\mathrm{AFB}_{1}$ contamination and a low percentage of post fermented samples. DON is one of the most common mycotoxins found in forage (Fink-Gremmels, 2008). The highest DON and ZEA concentrations were 3 month after ensilage and this result agreed with Storm et al. (2010) where the detected DON concentration in maize samples collected approximately 3 months after ensilage was $1056 \mu \mathrm{g} \mathrm{kg}^{-1}$. T-2 was present in some of the prefermented samples and in all samples 3 month after ensilage in study Storm et al. (2010) T-2 was present in two maize silages samples.

\section{CONCLUSIONS}

The current results indicate the presence of yeast, viable fungi spores and mycotoxins AFL (total), ZEA, DON, T-2 and OTA contamination in maize silage in Lithuania The main finding of this paper is that the risk of ZEA, DON, OTA mycotoxins contamination was highest in 3 months after ensilage and AFL (total), T-2 in 8 month after ensilage. The risk of fungal spoilage was highest 8 month after ensilage.

\section{REFERENCES}

1. AOAC. Association of Official Analytical Chemists. Official Methods of Analysis. 18th Gaithersburg, Maryland. International. 2005.

2. Baležentienè, L., Mikulionienè, S. 2006. Chemical composition of galega mixtures silages. Agronomy Research, Vol. 4, Iss. 2, pp. 483-492.

3. Baliukonienė, V., Bakutis, B., Vaivadaitè, T., Bartkienė, E., Jovaišienė, J. 2012. Prevalence of fungi and mycotoxins in silage and milk in Lithuania. Veterinarija ir Zootechnika, Vol. 59, Iss. 81, pp. 3-9.

4. Borucki, M. K., Gay, C. C., Reynolds, J., McElwain, K. L., Kim, S. H., Call, D. R., Knowles, D. P. 2005. Genetic diversity of Listeria monocytogenes strains from a high-prevalence dairy farm. Applied and Environmental Microbiology, Vol. 71, Iss. 10, pp. 5893-5899. http://dx.doi.org/10.1128/AEM.71.10.5893-5899.2005

5. European Food Safety Authority. 2004. Opinion of the Scientific Panel on Contaminants in the Food Chain on a request from the Commission related to Aflatoxin B1 as undesirable substance in animal feed. European Food Safety Authority Journal, Vol. 39, pp. 1-27.

6. Fink-Gremmels, J. 2008. The role of mycotoxins in the health and performance of dairy cows. The Veterinary Journal, Vol. 176, Iss. 1, pp. 84-92. http://dx.doi.org/10.1016/j.tvj1.2007.12.034

7. Garon, D., Richard, E., Sage, L., Bouchart, V., Pottier, D., Lebailly, P. 2006. Mycoflora and multimycotoxin detection in corn silage: experimental study. Journal of Agricultural and Food Chemistry, Vol. 54, Iss. 9, pp. 3479-3484. http://dx.doi.org/10.1021/jf060179i

8. Hawksworth, D. L., Kirk, P. M., Sutton, B. C., Pegler, D. N. 1995. Ainsworth and Bisby's dictionary of the fungi. 8th ed., Wallingford: CAB International.

9. Klich, M. A. 2002. Identification of Common Aspergillus Species. Centralbureau voor Schimmelcultures, Utrecht.

10. Lugauskas, A., Paškevičius, A., Repečkienè, J. 2002. Patogeniški ir toksiški mikroorganizmai žmogaus aplinkoje. Vilnius. 434 p. (in Lithuanian)

11. Nelson, P. E., Toussount, T. A., Marasas, W. F. O. 1983. Fusarium species. An illustrated manual for identification. The Pennsylvania State University Press. University Park, London.

12. Pereyra, M. L., Gonzalez, Alonso, V. A., Sager, R., Morlaco, M. B., Magnoli, C. E., Astoreca, A. L., Rosa, C. A. R., Chiacchiera, S. M., Dalcero, A. M., Cavaglieri, L. R. 2008. Fungi and selected mycotoxins from pre- and postfermented corn silage. Journal of Applied Microbiology, Vol. 104, pp. 1034-1041. http://dx.doi.org/10.1111/j.1365-2672.2007.03634.x

13. Pitt, J. I. 1997. Toxigenic Penicillium species. In: Doyle, M. P., Beuchat, L. R., Montville, T. J. (eds.) Food Microbiology, Fundamentals and Frontiers. ASM Press. Washington. DC., pp. 406-418.

14. Purwin, C., Łaniewska-Trokenheim, Ł., Warmińska-Radyko, I., Tywończuk, J. 2006. Jakość kiszonek-aspekty mikrobiologiczne, zdrowotne i produkcyjne. (Silage quality: microbiological, healt-promoting and production aspects). Medycyna Weterynaryjna, Vol. 62, Iss. 8, pp. 865-869. (In Polish)

15. Samson, R. A., Hoekstra, E. S., Frisvad, J. C., Filtenborg, O. 2002. Introduction to food - and airborne fungi. Utrecht, The Netherlands: Centraalbureau voor Schimmel cultures, $389 \mathrm{p}$.

16. Storm, I. M. L. D., Kristensen, N. B., Raun, B. M. L., Smedsgaard, J., Thrane, U. 2010. Dynamics in the microbiology of maize silage during whole season storage. Journal of Applied Mocrobiology, Vol. 109, Iss. 3, pp. $1017-1026$. $\underline{\text { http://dx.doi.org/10.1111/j.1365-2672.2010.04729.x }}$ 
17. Wilkinson, J. M., Toivonen, M. I. 2003. World Silage: a survey of forage conservation around the world. Lincoln: Chalcombe Publications, $204 \mathrm{p}$.

18. Yiannikouris, A., Jouany, J-P. 2002. Mycotoxins in feeds and their fate in animals: a review. Animal Research, Vol. 51, No. 2, pp. 81-99. http://dx.doi.org/10.1051/animres:2002012 